Tersedia Online di http://journal2.um.ac.id/index.php/jmsp/

ISSN Online : 2541-4429

\title{
ANALISIS TINDAK INDISIPLINER SISWA SMP NEGERI
}

\author{
Nova Revita Putri \\ e-mail: novarevita18@gmail.com \\ Kantor Bank Nasional Indonesia (BNI) \\ Jalan Panglima Sudirman No. 75 Blok A-8 Turen Malang
}

\begin{abstract}
The purpose of this research is done to know the student disciplinary action at every State Junior High School in Tempeh district. The type of this research is descriptive explorative with student disciplinary action variable. The results of this research are (1) the level of disciplinary action of junior high school students in Tempeh district is high, (2) the kinds of indiscipline acts that is when ditching the school students play with friends in the environment, while ditching the class, the students tend to be in the school canteen/cafeteria, incomplete uniform, while students are smoking at school parking, students are impolite to their schoolmates, students often criticize or mock, students play mobile phones during lessons, and students reply when there are others who disturb them that trigger on, and (3) the cause of the disciplinary action of the students of the State Junior High School in Tempeh subdistrict is an internal and external factor.
\end{abstract}

Keywords: indiscipline's act, infringement, students, junior high school

\begin{abstract}
Abstrak: Tujuan penelitian ini untuk mengetahui tindak indisipliner siswa SMP Negeri di Kecamatan Tempeh. Jenis penelitian ini adalah deskriptif eksploratif dengan variabel tindak indisipliner siswa. Hasil penelitian ini yaitu (1) tingkat tindak indisipliner siswa SMP Negeri di kecamatan Tempeh tergolong tinggi, (2) macam-macam tindak indisipliner yaitu saat membolos sekolah siswa bermain dengan teman di lingkungannya, saat membolos kelas, siswa cenderung berada di kantin/ kafetaria sekolah, siswa berseragam tidak lengkap, saat bersekolah siswa merokok di parkiran luar sekolah, siswa berlaku tidak sopan kepada teman sekolahnya, siswa sering mencela atau mengejek, siswa bermain telepon genggam (handphone) saat pelajaran berlangsung, serta siswa membalas ketika ada orang lain yang mengganggunya yang memicu pada pembalasan dendam, dan (3) penyebab tindak indisipliner siswa SMP Negeri di Kecamatan Tempeh adalah faktor internal dan faktor eksternal.
\end{abstract}

Kata kunci: tindak indisipliner, pelanggaran, siswa, SMP Negeri

Pendidikan mempunyai peranan yang sangat penting dalam proses kehidupan manusia termasuk para remaja. Proses pendidikan ditujukan untuk mengembangkan potensipotensi yang dimiliki manusia secara utuh dan menyeluruh dan melancarkan proses peralihan remaja untuk mencapai tingkat kedewasaan yang optimal. Untuk mencapai tujuan tersebut, maka sekolah merupakan salah satu lembaga pendidikan formal yang bertujuan untuk membina kepribadian anak- anak, remaja maupun manusia dewasa.

Sekolah berusaha mewujudkan upaya mencapai tingkat kedewasaan yang optimal bagi siswa dengan jalan melaksanakan programprogram pengajaran yang telah disesuaikan secara terstruktur berdasarkan tujuan kurikuler yang ada. Tetapi dalam pelaksanaannya, siswa terkadang tidak menerapkannya dengan baik dikarenakan kedisiplinan yang memudar oleh perkembangan zaman yang ada.

Menurut Rimm (2004:47), kedisiplinan mempunyai tujuan untuk mengarahkan anak agar mereka belajar mengenai hal-hal baik yang merupakan persiapan bagi masa dewasa, saat mereka sangat bergantung pada diri sendiri. 
Berdasarkan pendapat tersebut dapat disimpulkan bahwa disiplin sangat penting untuk menjadikan individu lebih terarah dalam menjalani kehidupannya. Siswa sebagai generasi penerus bangsa, sejak dini dapat dikenalkan dengan nilai-nilai yang mengatur kehidupan manusia yang berguna bagi diri sendiri dan masyarakat sekitarnya. Sedangkan zaman yang terus berkembang juga mempunyai dampak positif dan negatif untuk diri siswa yang tengah menjalani masa peralihan tersebut. Dampak negatif yang terjadi salah satunya adalah tingkat kenakalan remaja yang semakin tinggi dan banyak terjadi di sekolah. Kenakalan yang dilakukan siswa disebut pula dengan istilah perbuatan atau perilaku indisipliner siswa.

Berdasarkan studi di lapangan tersebut, peneliti menyimpulkan bahwa tingkat pemahaman kedisiplinan pada siswa pada SMP Negeri di Kecamatan Tempeh masih kurang. Hal ini diperkuat oleh pernyataan Bapak Ronny Kepala Sekolah SMP Negeri 3 Tempeh yang diwawancarai oleh peneliti pada hari sabtu, 2 April 2016 pada sekitar pukul 10.00 WIB, beliau mengatakan bahwa: "beberapa waktu yang lalu malah ada siswa yang melakukan tindakan sernonoh seperti memangku teman wanitanya di dalam kelas, dan ternyata dua siswa tersebut sudah bertunangan."

Perilaku indisipliner siswa yang semakin hari semakin meningkat, perlu dianalisis agar para pendidik dapat mengatasi perilaku tersebut dikarenakan sangat berdampak pada kegiatan pembelajaran. Salah satu bentuk dampaknya adalah ketika siswa berperilaku indisipliner, siswa yang bersangkutan tidak memiliki perhatian terhadap pembelajaran. Kemudian siswa tersebut tidak memelihara perilaku yang sesuai dengan ajaran di sekolah yang dapat merusak ketertiban suasana pembelajaran dan mengganggu siswa lain sehingga konsentrasi siswa lain akan terpecah. Selain itu perilaku indisipliner siswa merupakan tantangan bagi para pendidik yang harus diatasi dikarenakan pendidik merupakan orang tua siswa di sekolah. Dan pendidik harus mampu mendidik sifat dan sikap siswa di sekolah.

Disiplin sangat penting artinya bagi kehidupan manusia, karena itulah harus ditanamkan terus menerus terhadap individu. Dengan penanaman yang terus menerus, maka disiplin akan menjadi kebiasaan. Orang-orang yang berhasil dalam bidang pekerjaan, umumnya mempunyai kedisiplinan yang tinggi, sebaliknya orang-orang yang gagal umumnya tidak disiplin. Menurut Ariesandi (2008:230- 231) arti disiplin sesungguhnya adalah proses melatih pikiran dan karakter anak secara bertahap sehingga menjadi seseorang yang memiliki kontrol diri dan berguna bagi masyarakat.

Sedangkan menurut Wulandari (2014:12) disiplin dalam tata tertib kehidupan bila dirinci secara khusus dan terurai dari aspek demi aspek akan menghasilkan etika sebagai normanorma yang berlaku dalam pergaulan, termasuk juga dalam hubungan dengan lingkungan sekitar. Misalnya etika dalam pergaulan anak dengan orang tua, guru, cara berpakaian dan cara bersopan santun lainnya. Sedangkan penampilan, sikap dan tingkah laku seseorang dalam kehidupan, khususnya melalui pergaulan yang menggambarkan mampu atau tidaknya berdisiplin, bersopan santun, menerapkan normanorma kehidupan yang mulia berdasarkan agama islam sering disebut dengan akhlak.

Santrock (2007: 255) berpendapat bahwa kenakalan remaja merujuk pada berbagai perilaku mulai dari perilaku yang tidak dapat diterima secara sosial (seperti berbuat onar di sekolah), status pelanggaran (melarikan diri dari rumah), hingga tindakan kriminal. Pelanggaran disiplin sekolah adalah perbuatan melanggar aturan baik norma dan tata tertib yang ada di sekolah. Menurut Mulyadi (2003) pelanggaran disiplin disebut juga indisipliner siswa yang merupakan kenakalan yang sering dilakukan oleh siswa.

Setiap sekolah memiliki peraturan yang harus dilaksanakan dan dipatuhi oleh semua siswa. Peraturan yang dibuat di sekolah merupakan kebijakan sekolah yang tertulis dan berlaku sebagai standar untuk tingkah laku siswa sehingga siswa mengetahui batasanbatasan dalam bertingkah laku. Dalam disiplin terkandung pula ketaatan yang harus dilakukan setiap siswa dan setiap siswa juga harus mematuhi segala peraturan dan tanggung jawab. Menurut Djamarah dan Azwan (2006:201) bentuk-bentuk pelanggaran disiplin dibedakan menjadi dua yaitu bersifat individual dan bersifat kelompok.

Penanggulangan pelanggaran disiplin perlu dilakukan agar siswa dapat mengurangi dan tidak mengulangi dan paham bahwa yang dilakukan tidak sesuai dengan aturan dan norma 
yang berlaku. Menurut Prihatin (2011:94) penanggulangan pelanggaran disiplin dapat dilakukan dengan beberapa cara sebagai berikut (1) Pengenalan siswa; (2) Tindakan korektif yang meliputi tindakan dan bukan ceramah, don't bargain, gunakan kontrol kerja, dan menyatakan peraturan dan konsekuensinya dengan jelas; dan (3) Tindakan penyembuhan.

\section{METODE}

Penelitian ini menggunakan metode survei deskriptif eksploratif, karena bertujuan melakukan penjajakan guna menjelaskan tentang suatu fenomena yang ada saat ini dengan menggunakan angka- angka untuk menggambarkan karakteristik dan perkembangannya. Sedangkan penelitian eksploratif menurut Morissan (2012:35) merupakan penelitian awal yang bertujuan untuk mendapatkan gambaran mengenai suatu topik penelitian yang nantinya akan diteliti lebih jauh. Berdasarkan judul dan permasalahan yang akan dilakukan dalam penelitian ini, maka penelitian ini menggunakan satu variabel, yaitu tindak indisipliner siswa.

Dalam penelitian ini angket/ kuesioner digunakan untuk memperoleh data dari responden adalah jenis angket tertutup (multiple choice) dan angket terbuka. Skala dalam angket yang dipakai dalam penelitian ini menggunakan Skala Likert yang dimodifikasi. Menurut Sugiyono (2013: 93) Skala Likert digunakan untuk mengukur sikap, pendapat dan persepsi seseorang atau kelompok orang tentang fenomena sosial. Pilihan jawaban responden skala likert yang dimodifikasi diberi bobot nilai antara 1 (satu) sampai 4 (empat). Data yang digunakan dalam penelitian kuantitatif ini adalah data primer yang diperoleh langsung dari lapangan dengan cara membagikan kuisioner kepada responden yang menjadi sampel dalam penelitian pada variabel tindak indisipliner siswa. Sedangkan data sekunder diperoleh dari siswa yang di dapat di TU sekolah guna penghitungan sampel.

Teknik analisis data yang digunakan dalam penelitian ini adalah teknik analisis deskriptif. Menurut Sugiyono (2013: 147) "teknik analisis deskriptif digunakan untuk menganalisis sebagaimana adanya tanpa bermaksud membuat kesimpulan yang berlaku untuk umum atau generalis". Teknik analisis deskriptif pada dasarnya digunakan untuk mendeskripsikan suatu data.

\section{HASIL}

\section{Deskripsi Tindak Indisipliner Siswa}

Pengukuran pada tindak indisipliner siswa dilakukan dengan menggunakan keseluruhan angket yang mempunyai 28 butir soal. Pada angket yang menggunakan skala likert, penilaian masing-masing indikator pada 12 soal menggunakan kode 1-4. Dalam pengukuran ini peneliti menggunakan rumus statistika dengan penghitungan manual untuk mengetahui nilai interval dari data tindak indisipliner, diperoleh nilai minimal sebesar 24 dan nilai maksimal 40, sedangkan untuk nilai interval diperoleh 4 .

\section{Berikut Tabel 1 distribusi frekuensi untuk tindak indisipliner siswa SMP Negeri di seluruh Kecamatan Tempeh.}

\begin{tabular}{ccccc}
\hline No. & Interval & $\begin{array}{c}\text { Klasifikasi } \\
\text { Jawaban }\end{array}$ & Frekuensi & $\begin{array}{c}\text { Presentase } \\
(\%)\end{array}$ \\
\hline 1. & $36-40$ & $\begin{array}{c}\text { Sangat } \\
\text { Tinggi }\end{array}$ & 83 & 25,5 \\
2. & $32-35$ & Tinggi & 189 & 58,2 \\
3. & $28-31$ & Rendah & 46 & 14,2 \\
4. & $24-27$ & $\begin{array}{c}\text { Sangat } \\
\text { Rendah }\end{array}$ & 7 & 2,2 \\
\hline & Total & 325 & 100 \\
\hline
\end{tabular}

Berdasarkan Tabel 1 distribusi frekuensi tersebut, dapat diketahui bahwa dari 325 siswa Negeri di seluruh kecamatan Tempeh sebesar 2,2\% siswa memiliki kategori tindak indisipliner yang sangat rendah, 14,2\% memiliki kategori tindak indisipliner yang rendah, 58,2\% memiliki kategori tindak indisipliner yang tinggi.

Penilaian yang menggunakan angket tertutup, memiliki 4 opsi jawaban yaitu (a, b, c, d). Yang mana setiap opsi tidak memiliki tingkatan nilai. Dan terdapat beberapa variasi jawaban yang diisi oleh siswa untuk identifikasi macam- macam perilaku tentang tindak indisipliner siswa. 
Berikut Tabel 2 variasi jawaban untuk tindak indisipliner siswa SMP Negeri di seluruh Kecamatan Tempeh.

\begin{tabular}{|c|c|c|c|}
\hline No. & $\begin{array}{l}\text { No. } \\
\text { Item }\end{array}$ & Pilihan Jawaban & $\begin{array}{l}\text { Jumlah } \\
\text { pemilih }\end{array}$ \\
\hline \multirow[t]{4}{*}{1} & Item_2 & a. Membantu orang tua & 13 \\
\hline & & b. Bersantai di rumah & 14 \\
\hline & & $\begin{array}{l}\text { c. Bermain dengan teman } \\
\text { desa }\end{array}$ & 22 \\
\hline & & d. Bermain game di Warnet & 20 \\
\hline \multirow[t]{4}{*}{2} & Item_4 & a. Membersihkan musollah & 26 \\
\hline & & b. Berdiam diri di UKS & 47 \\
\hline & & c. Nongkrong di kantin & 59 \\
\hline & & d. Pacaran & 6 \\
\hline \multirow[t]{4}{*}{3} & Item_10 & a. Rapi & 204 \\
\hline & & b. Tidak memakai dasi & 59 \\
\hline & & c. Baju dikeluarkan & 33 \\
\hline & & $\begin{array}{l}\text { d. Tidak memakai dasi dan } \\
\text { baju dikeluarkan }\end{array}$ & 29 \\
\hline \multirow[t]{4}{*}{4} & Item_13 & a. Di luar gerbang sekolah & 9 \\
\hline & & b. Di parkiran luar sekolah & 43 \\
\hline & & c. Di toilet sekolah & 35 \\
\hline & & d. Di kantin sekolah & 21 \\
\hline \multirow[t]{4}{*}{5} & Item_14 & a. Teman sekolah & 174 \\
\hline & & b. Satpam sekolah & 73 \\
\hline & & c. Pegawai kantin & 57 \\
\hline & & d. Guru & 21 \\
\hline \multirow[t]{4}{*}{6} & Item_15 & a. Tidak ramah & 41 \\
\hline & & b. Tidak menghargai & 53 \\
\hline & & c. Mencela atau mengejek & 128 \\
\hline & & d. Berkata kasar & 103 \\
\hline \multirow[t]{4}{*}{7} & Item_16 & a. Menyimak guru mengajar & 85 \\
\hline & & b. Belajar pelajaran lain & 66 \\
\hline & & c. Bermain handphone & 91 \\
\hline & & d. Mengganggu teman & 83 \\
\hline \multirow[t]{4}{*}{8} & Item_18 & a. Diam saja & 105 \\
\hline & & b. Membalas & 146 \\
\hline & & c. Melapor ke guru & 51 \\
\hline & & d. Melapor ke orang tua & 23 \\
\hline
\end{tabular}

Berdasarkan Tabel 2 jawaban tersebut, dapat diketahui bahwa jawaban- jawaban tersebut adalah macam- macam tindak indisipliner yang dilakukan oleh siswa yang meliputi membolos, datang terlambat, melalaikan tugas, catatan tidak lengkap, tidak berseragam lengkap, malas mengikuti pelajaran, merokok, tidak sopan, tingkah laku menarik perhatian orang lain, tingkah laku menguasai orang lain, perilaku membalas dendam, dan peragaan ketidakmampuan.

\section{PEMBAHASAN}

\section{Persentase Tindak Indisipliner Siswa}

Pada hasil analisis deskriptif mengenai tindak indisipliner siswa SMP Negeri seluruh kecamatan Tempeh menunjukkan tingkat tindak indisipliner siswa sebesar $58,2 \%$ yang termasuk dalam kategori tinggi dengan jumlah responden sebanyak 189 siswa dari total 325 siswa. Tingkat tindak indisipliner siswa SMP Negeri seluruh kecamatan Tempeh berada pada rentang skor 32-35 dengan jumlah 189 siswa dari total 325 siswa termasuk dalam kategori tinggi. Sehingga dapat disimpulkan bahwa tindak indisipliner siswa SMP Negeri seluruh kecamatan Tempeh tergolong tinggi.

Pada dasarnya disiplin sekolah merupakan hal esensial yang menciptakan perilaku tidak menyimpang dari ketertiban sekolah. Menurut Imron (2012:173) "disiplin adalah suatu keadaan di mana sesuatu itu berada dalam keadaan tertib, teratur dan semestinya, serta ada suatu pelanggaran-pelanggaran baik secara langsung maupun tidak langsung". Misalnya etika dalam pergaulan anak dengan orang tua, guru, cara berpakaian dan cara bersopan santun lainnya. Sedangkan penampilan, sikap dan tingkah laku seseorang dalam kehidupan, khususnya melalui pergaulan yang menggambarkan mampu atau tidaknya berdisiplin, bersopan santun, menerapkan norma-norma kehidupan yang mulia berdasarkan agama islam sering disebut dengan akhlak.

Menurut Sahertian (dalam Imaniyah, 2010:22) "dua tujuan disiplin sekolah adalah (1) menolong anak menjadi matang pribadinya dan berubah dari sifat ketergantungan kearah tidak ketergantungan dan (b) mencegah timbulnya persoalan-persoalan disiplin dan menciptakan situasi dan kondisi dalam belajar mengajar agar mengikuti segala peraturan yang ada dengan penuh perhatian." Dapat ditarik kesimpulan bahwa disiplin sangat penting artinya bagi kehidupan manusia, karena itulah harus ditanamkan terus menerus terhadap individu. Dengan penanaman yang terus menerus, maka disiplin akan menjadi 
kebiasaan.

\section{Identifikasi Tindak Indisipliner Siswa}

Pada identifikasi mengenai macam- macam tindak indisipliner siswa SMP Negeri seluruh Kecamatan Tempeh menunjukkan macammacam tindak indisipliner yaitu (1) saat membolos sekolah siswa bermain dengan teman di lingkungannya, (2) saat membolos kelas, siswa cenderung berada di kantin/ cafetaria sekolah, (3) siswa berseragam rapi, (4) saat bersekolah siswa merokok di parkiran luar sekolah, (5) siswa berlaku tidak sopan kepada teman sekolahnya, (6) siswa sering mencela atau mengejek, (7) siswa bermain telepon genggam (handphone) saat pelajaran berlangsung, dan (8) siswa membalas ketika ada orang lain yang mengganggunya yang memicu pada pembalasan dendam.

Hasil penelitian ini didukung oleh pernyataan menurut Djamarah dan Azwan (2006:201) yaitu bentuk-bentuk pelanggaran disiplin dibedakan menjadi dua yaitu bersifat individual dan bersifat kelompok. Selanjutnya penelitian ini juga didukung oleh penelitian dengan judul "Kasus Perilaku Pelanggaran Disiplin Siswa di Sekolah ditinjau dari Kerangka Teori Sosiologi" oleh Sutrisno (2009) pada Jurnal Pendidikan Inovatif Jilid 4, Nomor 2, Maret 2009 yang menyatakan:

"Perilaku siswa yang sering melakukan pelanggaran disiplin di sekolah sebagai berikut, Pertama, semua subjek penelitian ini berperilaku sebagai siswa yang tidak berdisiplin. Hal ini ditunjukkan oleh perilaku mereka sehari-hari di sekolah yaitu membolos, datang terlambat, melalaikan tugas, catatan tidak lengkap, tidak berseragam lengkap, malas mengikuti pelajaran, acuh tak acuh pada waktu pelajaran, merokok, tidak sopan, mempengaruhi teman untuk melanggar disiplin, nongkrong di warung dekat sekolah, dan hiperaktif di kelas. Namun, ada juga subjek penelitian yang pendiam dan selalu bersikap sopan terhadap guru tetapi kenyataannya sering melakukan pelanggaran disiplin sekolah.”

Secara umum tujuan disiplin adalah mendidik seseorang agar dapat mengembangkan diri untuk melatih anak mengatur dirinya dan bertanggung jawab terhadap dirinya sendiri sehingga menjadi pribadi kearah tidak ketergantungan dan mengikuti segala peraturan. Disiplin di sekolah banyak digunakan untuk mengontrol tingkah laku siswa yang dikehendaki agar tugas-tugas di sekolah dapat berjalan dengan optimal. Menurut Ariwibowo (2014:17) tujuan disiplin tersebut berkenaan dengan pengendalian diri seseorang terhadap bentuk-bentuk aturan dan penataan perilaku seseorang agar menjadi pribadi yang baik sesuai dengan status sosial kelompok masyarakat.

Dapat disimpulkan bahwa seseorang yang disiplin, maka siswa dapat mengikuti pelajaran dengan baik sehingga tugas- tugas sekolah dan tujuan sekolah akan berjalan dan dapat dicapai dengan optimal sehingga tindak indisipliner yang tinggi diperlukan penanganan. Selain itu, kedisiplinan dapat memberikan kenyamanan pada para siswa dan staf (guru) serta menciptakan lingkungan yang kondusif untuk belajar serta perkembangan dari pengembangan diri sendiri dan pengarahan diri sendiri tanpa pengaruh atau kendali dari luar.

\section{Penyebab Tindak Indisipliner Siswa}

Pelanggaran disiplin dapat dilihat dari tingkah laku siswa itu sendiri karena tingkah laku anak didik sangatlah bervariasi. Menurut Hermatasiyah (2015) faktor atau penyebab pelanggaran disiplin adalah faktor internal yang berasal dari dalam diri siswa, dan faktor eksternal yang berasal dari luar diri siswa misalkan lingkungan siswa. Seluruh faktor penyebab tindak indisipliner tersebut dapat mempengaruhi tugas- tugas sekolah untuk membina siswa agar dapat mengikuti pelajaran dengan baik dan memiliki kepribadian yang baik.

Hasil dalam penelitian ini juga untuk mendeskripsikan faktor yang mempengaruhi siswa melakukan tindak indisipliner. Dan hasil penelitian menunjukkan bahwa faktor penyebab tindak indisipliner siswa adalah (1) faktor internal, yaitu malas menajdi penyebab membolos sekolah, belum mengerjakan PR menjadi penyebab membolos kelas, terlambat masuk kelas karena masih makan di kantin/ cafetaria sekolah, tidak mengerjakan tugas sekolah karena tidak belajar, lupa merupakan penyebab tidak memakai atribut berseragam lengkap, dan tidak disengaja menjadi penyebab berlaku tidak sopan; dan (2) faktor eksternal, yaitu menunggu teman untuk berangkat bersama menjadi penyebab terlambat berangkat sekolah, masih makan di kantin/cafetaria sekolah 
menjadi penyebab terlambat masuk kelas, guru yang terlalu cepat dalam menulis di papan tulis sehingga siswa tertinggal materi pelajaran menjadi penyebab siswa tidak mencatat materi pelajaran dengan lengkap, terpengaruh teman menjadi penyebab siswa merokok, dan diganggu oleh teman di kelas menjadi penyebab gaduh saat pelajaran.

Hasil penelitian ini didukung oleh penelitian yang berjudul "Faktor yang Mempengaruhi Pelanggaran Disiplin Siswa dan Implikasinya Terhadap Layanan Bimbingan \& Konseling" oleh Ilahi dkk (2013) pada Jurnal Ilmiah Konseling Volume 2, Nomor 2, Juni 2013. Hasilnya yaitu faktor yang dominan mempengaruhi pelanggaran disiplin siswa di SMAN X Padang adalah kondisi psikologis siswa itu sendiri, faktor eksternal yang dominan mempengaruhi pelanggaran disiplin siswa di SMAN X Padang adalah lingkungan sekolah, lingkungan keluarga dan lingkungan masyarakat, dan layanan bimbingan dan konseling di SMAN X Padang yang dapat diberikan adalah layanan informasi, layanan konseling perorangan, layanan penguasaan konten, dan layanan bimbingan kelompok.

Menurut Hermatasiyah (2015) terdiri dari "faktor internal adalah faktor yang berasal dari dalam diri siswa dan faktor eksternal merupakan faktor yang berasal dari luar diri siswa." Sehingga dapat disimpulkan bahwa penyebab siswa SMP Negeri di Kecamatan Tempeh melakukan tindak indisipliner siswa dikarenakan faktor internal dan faktor eksternal siswa.

\section{KESIMPULAN DAN SARAN}

\section{Kesimpulan}

Berdasarkan penelitian yang telah dilakukan, maka diperoleh beberapa kesimpulan, sebagai berikut, (1) tingkat tindak indisipliner siswa SMP Negeri seluruh Kecamatan Tempeh tergolong tinggi. Yang dibuktikan dengan hasil penelitian menunjukkan sebesar presentase tingkat tinda indisipliner siswa sebanyak 58,2\% yang termasuk dalam kategori tinggi dengan jumlah responden sebanyak 189 siswa dari total 325 siswa, (2) macam-macam perilaku tindak indisipliner siswa SMP Negeri di Kecamatan Tempeh yaitu (a) saat membolos sekolah siswa bermain dengan teman di lingkungannya, (b) saat membolos kelas, siswa cenderung berada di kantin/ cafetaria sekolah, (c) siswa berseragam tidak lengkap, (d) saat bersekolah siswa merokok di parkiran luar sekolah, (e) siswa berlaku tidak sopan kepada teman sekolahnya, (f) siswa sering mencela atau mengejek, (g) siswa bermain telepon genggam (handphone) saat pelajaran berlangsung, dan (h) siswa membalas ketika ada orang lain yang mengganggunya yang memicu pada pembalasan dendam, dan (3) penyebab tindak indisipliner siswa SMP Negeri di Kecamatan Tempeh terdiri dari dua faktor yaitu faktor internal, yaitu malas menajdi penyebab membolos sekolah, belum mengerjakan PR menjadi penyebab membolos kelas, terlambat masuk kelas karena masih makan di kantin/ cafetaria sekolah, tidak mengerjakan tugas sekolah karena tidak belajar, lupa merupakan penyebab tidak memakai atribut berseragam lengkap, dan tidak disengaja menjadi penyebab berlaku tidak sopan; dan (2) faktor eksternal, yaitu menunggu teman untuk berangkat bersama menjadi penyebab terlambat berangkat sekolah, masih makan di kantin/cafetaria sekolah menjadi penyebab terlambat masuk kelas, guru yang terlalu cepat dalam menulis di papan tulis sehingga siswa tertinggal materi pelajaran menjadi penyebab siswa tidak mencatat materi pelajaran dengan lengkap, terpengaruh teman menjadi penyebab siswa merokok, dan diganggu oleh teman di kelas menjadi penyebab gaduh saat pelajaran.

\section{Saran}

Berdasarkan kesimpulan dari penelitian ini, diajukan beberapa saran bagi (1) Kepala Sekolah SMP Negeri di Kecamatan Tempeh yaitu diharapkan hasil penelitian ini dapat dijadikan bahan evaluasi untuk meningkatkan disiplin sekolah dengan membentuk polisi tatib, menciptakan iklim yang kondusif, memperbaharui tata tertib di sekolah untuk guru dan siswa tentang kedisiplinan agar pembelajaran di sekolah semakin efektif dan efisien. Bekerja sama dengan orang tua siswa dalam mengatasi masalah pelanggaran disiplin dengan melakukan sosialisasi rutin agar orang tua lebih mengerti betapa pentingnya pendidikan dalam membentuk karakter siswa. Bagi sekolah yang belum memiliki guru BK, diharapkan Kepala Sekolah segera membentuk guru BK di sekolah, (2) Guru SMP Negeri di Kecamatan Tempeh diharapkan hasil penelitian ini dapat dijadikan bahan evaluasi 
untuk (a) Guru BK yaitu bekerja sama dengan guru piket dan guru kelas dan lebih sering berkeliling untuk mengecek keadaan siswa agar siswa tidak mempunyai kesempatan untuk melakukan tindak indisipliner sehingga pembelajaran dapat berjalan secara efektif dan efisien, (b) Guru Kelas hendaknya bekerja sama dengan guru mata pelajaran dan guru BK dalam mengatasi masalah tindak indisipliner siswa agar siswa dapat belajar bertingkah laku disiplin dan bekerja sama dalam menciptakan iklim yang kondusif, (c) Guru Piket lebih ketat lagi dalam mengecek siswa yang terlambat, bukan hanya terlambat masuk sekolah tetapi juga saat masuk kelas, dan mempertegas sanksi yang ada agar siswa jera melakukan tindak indisipliner, dan (d) Guru Mata Pelajaran hendaknya lebih memperhatikan catatan siswa dan tidak terlalu cepat dalam menulis ataupun menjelaskan materi di kelas agar pembelajaran di kelas dapat berjalan lancar dan dapat menghambat faktor-faktor penyebab pelanggaran disiplin, kemudian (3) Orang Tua Siswa SMP Negeri di Kecamatan Tempeh hendaknya orang tua siswa lebih memperhatikan dalam pendidikan anaknya, seperti mengecek catatan anak, mengecek tugas sekolah anak dan memantau perilaku anak. Memprioritaskan anak dalam hal pendidikan dan mengikuti sosialisasi yang diadakan oleh sekolah, (4) Mahasiswa Jurusan Administrasi Pendidikan dapat menjadikan penelitian ini sebagai bahan rujukan dalam proses perkuliahan, dan sebagai bahan rujukan dalam kegiatan penelitian selanjutnya dan (5) bagi Peneliti La yang berminat dan tertarik untuk penelitian serupa, diharapkan dapat mengkaji lebih lengkap, mampu menyempurnakan penelitian ini, dan dapat mengembangkan hasil penelitian ini dengan menambahkan variabel lain yang belum diteliti, antara lain: disiplin siswa, dan motivasi siswa.

\section{DAFTAR RUJUKAN}

Ariesandi. 2008. Rahasia Mendidik Anak Agar Sukses dan Bahagia, Tips dan Terpuji Melejitkan Potensi Optimal Anak. Jakarta: PT Gramedia Pustaka Utama.

Ariwibowo, A. 2014. Penanaman Nilai Disiplin di Sekolah Dasar Negeri Suryowijayan Yogyakarta. Skripsi tidak diterbitkan. Yogyakarta: PGSD FIP UNY.

Djamarah, Syaiful B. dan Azwan, Z. 2006. Strategi
Belajar Mengajar. Jakarta: PT Rineka Cipta.

Hermatasiyah, N. 2015. Faktor Penyebab Pelanggaran Disiplin pada Siswa SMP Negeri 19 Kota Jambi. BK FKIP Universitas Jambi. (Online), (http:// www.e-campus.fkip.unja.ac.id/eskripsi/data/pdf/ jurnal_mhs/artikel/ERA1D010159.pdf), diakses 17 April 2016.

Ilahi, dkk. 2013. Faktor yang Mempengaruhi Pelanggaran Disiplin Siswa dan Implikasinya Terhadap Layanan Bimbingan dan Konseling. Jurnal Ilmiah Konseling. 2 (2). (Online), (http:// download.portalgaruda.org.article) diakses 1 Agutsus 2017.

Imaniyah. 2010. Efektivitas Kedisiplinan Siswa dalam Pembelajaran di SMP Islamiyah Ciputat. Skripsi tidak diterbitkan. Jakarta: PAI FITK UIN Syarif Hidayatullah.

Imron, A. 2012. Manajemen Peserta Didik Berbasis Sekolah. Jakarta: Bumi Aksara.

Morissan. 2012. Metode Penelitian Survei. Jakarta: PT Fajar Interpratama Mandiri.

Mulyadi, Y. 2003. Jenis- Jenis Perilaku Indisipliner Siswa dan Upaya Mengatasinya dalam Pengajaran PPKn. Tesis tidak diterbitkan. Bandung: Pascasarjana UPI.

Prihatin, E 2011. Manajemen Peserta Didik. Bandung: Alfabeta.

Rimm, S. 2004. Mendidik dan Menerapkan Disiplin pada Anak Prasekolah. Alih Bahasa: Lina Yusuf. Jakarta: PT. Gramedia Pustaka Utama.

Santrock, J. 2007. Adolescence (jilid 2). Alih Bahasa: Benedictine Widyasinta. Jakarta: Erlangga.

Sugiyono. 2013. Metode Penelitian Kuantitatif Kualitatif dan R\&D. Bandung: Alfabeta.

Sutrisno, H. 2009. Kasus Perilaku Pelanggaran Disiplin Siswa di Sekolah ditinjau dari Kerangka Teori Sosiologi. Jurnal Pendidikan, 4 (2). (Online), $\mathrm{x}$ (http://jurnaljpi.files.wordpress.com>volume-4. html) diakses 30 April 2016.

Wulandari, M. 2014. Upaya Meningkatkan Kedisiplinan Siswa Melalui Proses Pembelajaran Pendidikan Kewarganegaraan. Jurnal Ilmiah PPKN IKIP Veteran Semarang, 2 (1): 44- 53. 